medRxiv preprint doi: https://doi.org/10.1101/2021.03.10.21252749; this version posted March 12, 2021. The copyright holder for this preprint (which was not certified by peer review) is the author/funder, who has granted medRxiv a license to display the preprint in perpetuity.

All rights reserved. No reuse allowed without permission.

\title{
Therapeutic Anticoagulation in Critically III Patients with Covid-19 - Preliminary Report
}

\author{
The REMAP-CAP, ACTIV-4a, and ATTACC Investigators
}

\section{Author and Group Information}

The members of the writing committee appear at the end of the main text and the full list of investigators and collaborators appear in the Supplementary Appendix.

\section{Keywords:}

anticoagulation, heparin, low molecular weight heparin, Covid-19, adaptive platform trial, critical care

\section{Corresponding author:}

Ryan Zarychanski, MD MSc

Sections of Hematology/Oncology and Critical Care

University of Manitoba

Winnipeg, Manitoba, Canada R3E OV9

email: rzarychanski@cancercare.mb.ca 


\section{Abstract}

\section{Background}

Thrombosis may contribute to morbidity and mortality in Covid-19. We hypothesized that therapeutic anticoagulation would improve outcomes in critically ill patients with Covid-19.

\section{Methods}

We conducted an open-label, adaptive, multiplatform, randomized, clinical trial. Patients with severe Covid-19, defined as the requirement for organ support with high flow nasal cannula, non-invasive ventilation, invasive ventilation, vasopressors, or inotropes, were randomized to receive therapeutic anticoagulation with heparin or pharmacological thromboprophylaxis as per local usual care. The primary outcome was an ordinal scale combining in-hospital mortality (assigned -1) and days free of organ support to day 21.

\section{Results}

Therapeutic anticoagulation met the pre-defined criteria for futility in patients with severe Covid-19. The primary outcome was available for 1,074 participants ( 529 randomized to therapeutic anticoagulation and 545 randomized to usual care pharmacological thromboprophylaxis). Median organ support-free days were 3 days (interquartile range $-1,16$ ) in patients assigned to therapeutic anticoagulation and 5 days (interquartile range $-1,16$ ) in patients assigned to usual care pharmacological thromboprophylaxis (adjusted odds ratio 0.87, 95\% credible interval ( $\mathrm{Crl}$ ) $0.70-1.08$, posterior probability of futility [odds ratio<1.2] 99.8\%). Hospital survival was comparable between groups (64.3\% vs. $65.3 \%$, adjusted odds ratio 0.88 , $95 \% \mathrm{Crl}$ 0.67-1.16). Major bleeding occurred in 3.1\% of patients assigned to therapeutic anticoagulation and $2.4 \%$ of patients assigned to usual care pharmacological thromboprophylaxis.

\section{Conclusions}

In patients with severe Covid-19, therapeutic anticoagulation did not improve hospital survival or days free of organ support compared to usual care pharmacological thromboprophylaxis.

Trial registration numbers NCT02735707, NCT04505774, NCT04359277, NCT04372589 


\section{Background}

Observational studies identified an association between the novel coronavirus disease 2019

(Covid-19), inflammation, hypercoagulability, and thrombosis. ${ }^{1-4}$ Critically ill patients with

Covid-19 are at high risk of venous and arterial thrombotic events despite standard dose pharmacological thromboprophylaxis. ${ }^{5-8}$ Higher levels of circulating biomarkers reflecting systemic inflammation and coagulation activation (e.g., D-dimer, C-reactive protein) are independently associated with a greater risk of respiratory failure, thrombosis, and death. 2,9,10 Thrombotic processes may therefore be an important cause of poor outcome from Covid-19. Unfractionated and low molecular weight heparins are parenteral anticoagulants with anti-inflammatory properties and possible antiviral properties. ${ }^{11,12}$ On the basis of clinical and pathologic reports of excess thrombotic risk enhanced dose anticoagulation strategies have been incorporated into some Covid-19 guidance statements, especially for critically ill patients. ${ }^{13,14}$ However, the effectiveness and safety of empiric full dose anticoagulation to improve outcomes in Covid-19 has not been established.

To determine whether a pragmatic strategy of therapeutic dose anticoagulation improves survival and reduces the duration of organ support compared to usual care pharmacological thromboprophylaxis in critically ill patients with Covid-19, we conducted an international multiplatform randomized clinical trial (mpRCT). 


\section{Methods}

\section{Trial Design and Oversight}

Early in the Covid-19 pandemic, the lead investigators of three international adaptive platform trials harmonized their protocols to study the effect of therapeutic anticoagulation in patients hospitalized for Covid-19 into one integrated $\mathrm{mpRCT}$ to accelerate evidence generation and maximize external validity of results (see Protocol Appendix, p. 29). The participating platforms included Randomized, Embedded, Multifactorial Adaptive Platform Trial for CommunityAcquired Pneumonia (REMAP-CAP; NCT02735707) ${ }^{15}$, Accelerating Covid-19 Therapeutic Interventions and Vaccines-4 Antithrombotics Inpatient platform trial (ACTIV-4a; NCT04505774 and NCT04359277), and Antithrombotic Therapy to Ameliorate Complications of Covid-19 (ATTACC; NCT04372589). ${ }^{16}$ The three platforms aligned the trial design, eligibility criteria, interventions, outcome measures, and statistical analysis plan a priori to execute the mpRCT. Each platform was overseen by independent data and safety monitoring boards (DSMB) and collaboratively guided a cross-platform DSMB interaction plan (see Protocol Appendix, p. 155).

The platforms enrolled patients hospitalized for Covid-19. Although REMAP-CAP enrolled patients with suspected or confirmed Covid-19, only participants with confirmed infection were included in the mpRCT primary analysis. The mpRCT was designed to evaluate the effect of therapeutic anticoagulation in four patient groups: severe Covid-19, or moderate Covid-19 stratified by degree of D-dimer elevation (high, low, or missing). The stopping criteria for a statistical conclusion applied independently to each of the groups except for the group with missing D-dimer. 
medRxiv preprint doi: https://doi.org/10.1101/2021.03.10.21252749; this version posted March 12, 2021. The copyright holder for this preprint (which was not certified by peer review) is the author/funder, who has granted medRxiv a license to display the preprint in perpetuity.

All rights reserved. No reuse allowed without permission.

Severe Covid-19 was defined as the provision of intensive care unit-level respiratory or cardiovascular organ support (high flow nasal oxygen $\geq 20 \mathrm{~L} / \mathrm{min}$, non-invasive or invasive mechanical ventilation, extracorporeal life support, vasopressors, or inotropes). Patients were ineligible if they were admitted to the ICU with Covid-19 for more than 48 hours (REMAP-CAP) or to hospital for more than 72 hours (ACTIV-4a, ATTACC) prior to randomization, at imminent risk of death without an ongoing commitment to full organ support, at high risk of bleeding, receiving dual antiplatelet therapy, had a separate clinical indication for therapeutic anticoagulation, or had a history of heparin sensitivity including heparin-induced thrombocytopenia. Detailed exclusion criteria for the platforms are provided in the Protocol Appendix (p. 29).

The mpRCT was conducted in accordance with the principles of the Good Clinical Practice guidelines of the International Conference on Harmonization. Ethics and regulatory approval were obtained at each participating center. The trial was supported by multiple international funding organizations who had no role in the analysis or reporting of the trial result.

\section{Randomization}

Randomization was performed using central web-based systems. Participants were randomized to receive therapeutic anticoagulation with unfractionated or low molecular weight heparin or usual care pharmacological thromboprophylaxis in an open label fashion. ACTIV-4a randomized all participants in a 1:1 ratio. The other two platforms specified responseadaptive randomization; randomization probabilities were updated in the severe patient group 
medRxiv preprint doi: https://doi.org/10.1101/2021.03.10.21252749; this version posted March 12, 2021. The copyright holder for this preprint (which was not certified by peer review) is the author/funder, who has granted medRxiv a license to display the preprint in perpetuity.

All rights reserved. No reuse allowed without permission.

within REMAP-CAP and ATTACC during the interim period between the mpRCT interim data cut and the halt of enrollment.

Therapeutic anticoagulation was administered according to local site protocols for the treatment of acute venous thromboembolism for up to 14 days or recovery (defined as hospital discharge, or liberation from supplemental oxygen for at least 24 hours). Usual care pharmacological thromboprophylaxis was administered according to local practice or with guidance from the trial protocol on maximum dosing, which included either standard low dose thromboprophylaxis or enhanced intermediate dose thromboprophylaxis. A subset of participants enrolled in REMAP-CAP were also randomized in the antiplatelet agent domain and in other domains of that trial.

\section{Outcome measures}

The primary outcome, organ support-free days (OSFDs), was an ordinal scale composed of survival to hospital discharge and, in survivors, the number of days free of organ support to day 21. Death in hospital through day 90 was assigned the worst outcome (-1). Among hospital survivors, the number of days free of respiratory organ support (high flow nasal cannula, noninvasive or invasive ventilation, extracorporeal life support) and cardiovascular organ support (vasopressors or inotropes) through day 21 were recorded. A higher value for OSFDs indicates a better outcome. A participant who was discharged from hospital prior to day 21 was assumed to be alive and free of organ support through 21 days. Pre-specified secondary outcomes included survival to day 90, major thrombotic events or death (a composite of myocardial infarction, pulmonary embolism, ischemic stroke, systemic arterial embolism, and in-hospital 
medRxiv preprint doi: https://doi.org/10.1101/2021.03.10.21252749; this version posted March 12, 2021. The copyright holder for this preprint (which was not certified by peer review) is the author/funder, who has granted medRxiv a license to display the preprint in perpetuity.

All rights reserved. No reuse allowed without permission.

death) through to 28 days (ACTIV-4a, ATTACC) or through to hospital discharge (REMAP-CAP).

Safety outcomes included major bleeding during the treatment period as defined by the International Society of Thrombosis and Haemostasis for non-surgical patients ${ }^{17}$ and laboratoryconfirmed heparin-induced thrombocytopenia. Thrombotic and bleeding events were adjudicated by independent platform-specific adjudication committees blinded to treatment assignment (Protocol Appendix, p. 478).

\section{Statistical Analysis}

Although the platforms enrolled participants independently, the mpRCT analyzed combined individual participant-level data from all platforms using a single overarching Bayesian model (see Protocol Appendix, p. 35). Monthly interim analyses of combined data from all platforms were planned within each of the pre-specified patient groups. Randomization continued within each group until a statistical conclusion of superiority (defined as a $>99 \%$ posterior probability of proportional odds ratio $>1$ ) or futility (>95\% posterior probability of proportional odds ratio<1.2) was met for a group.

The primary analysis was a Bayesian cumulative logistic model that calculated the posterior probability distribution for the proportional odds ratio for OSFDs. An odds ratio greater than 1 indicates a better outcome with therapeutic anticoagulation. The primary model adjusted for age (categorized into six groups), sex, site, and time period (2-week epochs). The model estimated treatment effects for each of the patient groups (severe, and moderate stratified by D-dimer), utilizing a Bayesian hierarchical approach, which dynamically borrows information between groups if the observed effects are similar between groups. ${ }^{18}$ If, at an interim analysis, 
medRxiv preprint doi: https://doi.org/10.1101/2021.03.10.21252749; this version posted March 12, 2021. The copyright holder for this preprint (which was not certified by peer review) is the author/funder, who has granted medRxiv a license to display the preprint in perpetuity.

All rights reserved. No reuse allowed without permission.

a statistical criteria was reached in one group and not the others, only outcomes for participants in that group would be unblinded. For the purposes of this report, the primary analysis was run on all participants enrolled in the mpRCT (including both moderate and severe patient groups) for whom the primary endpoint was available at the date of database lock, January 28,2021 . The analysis of this dataset was pre-specified in a sub-statistical analysis plan for this preliminary report of the results (see Protocol Appendix, p. 120).

The primary model was fit using a Markov Chain Monte Carlo algorithm with 100,000 samples from the joint posterior distribution, allowing calculation of the posterior distributions for the odds ratios, including medians and 95\% credible intervals (Crls) and the posterior probabilities of superiority (odds ratio $>1$ ), futility (odds ratio<1.2), or inferiority (odds ratio<1). A similar model was run for survival to hospital discharge (a key subcomponent of OSFDs). The pre-specified sensitivity analyses of the primary model are described in the Statistical Analysis Plan (Supplementary Appendix). To assess the influence of potential prior enthusiasm for therapeutic anticoagulation, a sensitivity analysis was conducted using an enthusiastic prior (prior mean OR 1.75, 95\% Crl 0.74-4.15; prior probability of superiority 90\%).

For the key secondary endpoints, similar models were restricted to the severe patient group, without borrowing information from moderate patient groups. Per-protocol analyses were conducted restricted to participants who received a dose of study treatment consistent with their treatment assignment in the trial within 24 hours of randomization (see Protocol Appendix for details on this classification). Subgroup analyses assessed whether treatment effect varied according to age, sex, requirement for mechanical ventilation at baseline, and 
medRxiv preprint doi: https://doi.org/10.1101/2021.03.10.21252749; this version posted March 12, 2021. The copyright holder for this preprint (which was not certified by peer review) is the author/funder, who has granted medRxiv a license to display the preprint in perpetuity.

All rights reserved. No reuse allowed without permission.

intensity of thromboprophylaxis dosing in the usual care arm (defined based on the pattern of practice at each participating site, see Protocol Appendix).

\section{Results}

The first participant was randomized on April 21, 2020. Enrollment was discontinued in the severe patient group on December $19^{\text {th }} 2020$ after an interim analysis demonstrated that the statistical criteria for futility was met. At that time a total of 1,205 participants with severe suspected or confirmed Covid-19 were randomized (Figure 1). Of these, 25 participants withdrew consent, 91 participants did not have laboratory-confirmed Covid-19, and the primary outcome was not available in 15 participants as of January 28,2021 . The current report presents the results of the primary analysis for 1,074 participants with severe confirmed Covid-

19.

\section{Participants}

Baseline characteristics were comparable between the intervention groups (Table 1). The majority of participants were enrolled through the REMAP-CAP platform ( $n=987,84 \%$, Table S1). The pattern of heparin administration in the intervention groups is described in Table S1. In participants randomized to usual care pharmacological thromboprophylaxis, the initial postrandomization dose equivalent corresponded to standard low dose thromboprophylaxis in $41 \%$ of participants in whom these data were available and to enhanced intermediate dose thromboprophylaxis in 51\% of participants in whom these data were available (Table S1).

\section{Primary Outcome}


medRxiv preprint doi: https://doi.org/10.1101/2021.03.10.21252749; this version posted March 12, 2021. The copyright holder for this preprint (which was not certified by peer review) is the author/funder, who has granted medRxiv a license to display the preprint in perpetuity.

All rights reserved. No reuse allowed without permission.

In participants assigned to therapeutic anticoagulation, the median value for organ support-

free days was 3 (interquartile range $-1,16$ ); in participants assigned to usual care pharmacological thromboprophylaxis the median value was 5 (interquartile range $-1,16$ ). In the primary model, the median adjusted proportional odds ratio for the effect of therapeutic anticoagulation on organ support-free days was 0.87 (95\% $\mathrm{Crl} 0.70-1.08)$, yielding a posterior probability of futility of $99.8 \%$ and a posterior probability of inferiority of $89.4 \%$ (Table 2 and Figure 2). In-hospital survival was $64.3 \%$ in participants assigned to therapeutic anticoagulation and $65.3 \%$ in participants assigned to usual care pharmacological thromboprophylaxis (median adjusted odds ratio $0.88,95 \% \mathrm{Crl} 0.67-1.16$; posterior probability of inferiority $81.0 \%$ ). Survival to day 90 is shown in Figure 3.

In sensitivity analyses of the primary outcome (Table S2), incorporation of prior enthusiasm for therapeutic anticoagulation did not modify the conclusion (median adjusted proportional odds ratio $0.89,95 \%$ Crl $0.72-1.10)$. Restricting to participants managed per-protocol gave similar results (median adjusted proportional odds ratio $0.94,95 \% \mathrm{Crl} 0.70-1.25$ ). Including participants with suspected Covid-19 and excluding participants with concomitantly receiving an antiplatelet agent at baseline or those enrolled in the REMAP-CAP antiplatelet agent domain also yielded similar results (Table S2). In pre-specified subgroup analyses, the estimated effect did not meaningfully vary according to age, sex, baseline requirement for invasive mechanical ventilation, or the pattern of usual care pharmacological thromboprophylaxis dosing at sites (intermediate vs. low dose) (Figure S1).

\section{Secondary Outcomes}


medRxiv preprint doi: https://doi.org/10.1101/2021.03.10.21252749; this version posted March 12, 2021. The copyright holder for this preprint (which was not certified by peer review) is the author/funder, who has granted medRxiv a license to display the preprint in perpetuity.

All rights reserved. No reuse allowed without permission.

Major thrombotic events or death are reported in Table 2. Although there were numerically fewer participants with major thrombotic events among those assigned to therapeutic anticoagulation in comparison to those assigned to usual care pharmacological thromboprophylaxis (5.7\% vs. $10.3 \%)$, the secondary efficacy outcome of major thrombotic events or death was similar between groups (41.4\% vs. $42.7 \%$, median adjusted odds ratio 1.05 , 95\% Crl 0.79-1.40). A breakdown of major thrombotic events is provided in Table S3. A major bleeding event occurred during the treatment period in $3.1 \%$ of participants assigned to therapeutic anticoagulation and in $2.4 \%$ of participants assigned to usual care pharmacological thromboprophylaxis. 


\section{Discussion}

In this international multiplatform randomized clinical trial of over 1,000 critically ill patients with confirmed Covid-19, therapeutic anticoagulation did not improve survival or days free of organ support and had an $89 \%$ probability of being inferior to usual care pharmacological thromboprophylaxis. There was an $81 \%$ probability that therapeutic anticoagulation reduced survival to hospital discharge in comparison to usual care pharmacological thromboprophylaxis. Bleeding complications were infrequent in both groups. Although therapeutic anticoagulation resulted in a numerical decrease in major thrombotic events, it did not improve organ supportfree days or survival to hospital discharge.

Our results refute the hypothesis that, in the absence of a usual clinical indication for therapeutic anticoagulation, empiric administration of therapeutic anticoagulation benefits critically ill patients with Covid-19. This hypothesis was based on observational studies that reported therapeutic anticoagulation was associated with improved outcomes, particularly in critically ill patients. ${ }^{14,19,20}$ Multiple small and moderate-size randomized trials continue to evaluate different anticoagulation strategies in Covid-19. ${ }^{21}$ The results of this study demonstrate that, in critically ill patients with Covid-19, the probability of benefit from a routine full-dose therapeutic anticoagulation strategy is low.

The net effect of enhanced anticoagulation on clinical outcome may depend on the degree of coagulation or inflammation or on the timing of initiation in relation to disease course. As has been reported for other therapies used in Covid-19, the effectiveness of anticoagulation in Covid-19 may vary with the severity of illness when therapy is commenced. ${ }^{22-}$

${ }^{24}$ Despite demonstrable activation of coagulation and systemic inflammation in severe Covid- 
medRxiv preprint doi: https://doi.org/10.1101/2021.03.10.21252749; this version posted March 12, 2021. The copyright holder for this preprint (which was not certified by peer review) is the author/funder, who has granted medRxiv a license to display the preprint in perpetuity.

All rights reserved. No reuse allowed without permission.

19 , our findings suggest that initiating therapeutic anticoagulation once patients develop severe

Covid-19 may be too late to reasonably alter the consequences of established disease pathology. The net clinical effect of anticoagulation might also be modified by the use of concomitant immunomodulatory therapies.

In this trial, the probability of inferiority of therapeutic anticoagulation was $89 \%$. Mechanisms that could account for this likely harm are uncertain. Although major bleeding was numerically increased with therapeutic anticoagulation, the occurrence of major bleeding with full-dose therapeutic anticoagulation was low (3.1\%) and consistent with previous estimates of bleeding in critically ill patients. ${ }^{25}$ In patients with Covid-19 and severe ARDS, autopsy findings include microthrombosis but also alveolar hemorrhage. ${ }^{26}$ It is possible that, in the presence of marked pulmonary inflammation, therapeutic anticoagulation could exacerbate alveolar hemorrhage leading to worse outcome.

This trial was made possible through a major global collaboration to conduct what is, to our knowledge, the first multiplatform clinical trial whereby a harmonized pragmatic trial protocol was actioned by three platform networks spanning five continents. The interventions evaluated are familiar and widely accessible, rendering the findings highly applicable to critically ill patients with severe Covid-19 disease. Analyses were pre-specified using a Bayesian framework that incorporated frequent interim analyses. Through a combined effort to collaboratively inform practice, we reached a trial conclusion for futility with probable harm more quickly than would have been possible as independent platforms.

One limitation of our trial is the open-label design, although clinician or participant awareness likely had little or no impact on the primary outcome that incorporated mortality 
and duration of organ support. The open label strategy may also introduce systematic bias in the ascertainment of thrombotic events. Additionally, the pragmatic design of this trial allowed clinicians to employ local site practice in the usual care pharmacological thromboprophylaxis arm. A substantial majority of enrollment in the severe patient group was in the United Kingdom where national practice guidelines changed during the trial to recommend that Covid19 patients admitted to an ICU receive intermediate dose anticoagulation for thromboprophylaxis. Many participants in the usual care arm therefore received an intermediate dose of thromboprophylaxis. It is possible that the benefit of therapeutic anticoagulation varies according to management of the comparator group. However, in prespecified subgroup analyses, the treatment effect of therapeutic dose anticoagulation did not vary meaningfully according to site proclivity for low or intermediate dose thromboprophylaxis. Whether intermediate dose thromboprophylaxis is superior to standard low dose thromboprophylaxis in critically ill patients is uncertain. Moreover, the effect of therapeutic anticoagulation in hospitalized, non critically ill patients with Covid-19 remains to be determined.

In conclusion, in critically ill patients with Covid-19, there was no benefit of therapeutic anticoagulation with heparin compared to usual care pharmacological thromboprophylaxis and a high probability of inferiority. 
medRxiv preprint doi: https://doi.org/10.1101/2021.03.10.21252749; this version posted March 12, 2021. The copyright holder for this preprint (which was not certified by peer review) is the author/funder, who has granted medRxiv a license to display the preprint in perpetuity. All rights reserved. No reuse allowed without permission.

\section{Acknowledgements}

We are grateful for the support of the participants and their families who participated in this trial. We thank those who served on the Data Safety and Monitoring Boards of each platform; we gratefully acknowledge the support of multiple funding organizations for the participating platforms (see Supplementary Appendix). 


\section{References}

1. Klok FA, Kruip M, van der Meer NJM, et al. Confirmation of the high cumulative incidence of thrombotic complications in critically ill ICU patients with COVID-19: An updated analysis. Thromb Res 2020;191:148-150. DOI: 10.1016/j.thromres.2020.04.041.

2. Middeldorp S, Coppens M, van Haaps TF, et al. Incidence of venous thromboembolism in hospitalized patients with COVID-19. J Thromb Haemost 2020;18(8):1995-2002. DOI: $10.1111 /$ jth.14888.

3. Smilowitz NR, Kunichoff D, Garshick M, et al. C-reactive protein and clinical outcomes in patients with COVID-19. Eur Heart J 2021. DOI: 10.1093/eurheartj/ehaa1103.

4. Nopp S, Moik F, Jilma B, Pabinger I, Ay C. Risk of venous thromboembolism in patients with COVID-19: A systematic review and meta-analysis. Res Pract Thromb Haemost 2020. DOI: $10.1002 /$ rth2.12439.

5. Poissy J, Goutay J, Caplan M, et al. Pulmonary Embolism in Patients With COVID-19: Awareness of an Increased Prevalence. Circulation 2020;142(2):184-186. DOI: 10.1161/CIRCULATIONAHA.120.047430.

6. Helms J, Tacquard C, Severac F, et al. High risk of thrombosis in patients with severe SARS-CoV-2 infection: a multicenter prospective cohort study. Intensive Care Med 2020;46(6):1089-1098. DOI: 10.1007/s00134-020-06062-x.

7. Godoy LC, Goligher EC, Lawler PR, Slutsky AS, Zarychanski R. Anticipating and managing coagulopathy and thrombotic manifestations of severe COVID-19. CMAJ 2020;192(40):E1156-E1161. DOI: 10.1503/cmaj.201240.

8. Bilaloglu S, Aphinyanaphongs $Y$, Jones S, Iturrate $E$, Hochman J, Berger JS. Thrombosis in Hospitalized Patients With COVID-19 in a New York City Health System. JAMA 2020;324(8):799-801. DOI: 10.1001/jama.2020.13372.

9. Zhou F, Yu T, Du R, et al. Clinical course and risk factors for mortality of adult inpatients with COVID-19 in Wuhan, China: a retrospective cohort study. Lancet 2020;395(10229):1054-1062. DOI: 10.1016/S0140-6736(20)30566-3.

10. Al-Samkari H, Karp Leaf RS, Dzik WH, et al. COVID-19 and coagulation: bleeding and thrombotic manifestations of SARS-CoV-2 infection. Blood 2020;136(4):489-500. DOI: 10.1182/blood.2020006520.

11. Poterucha TJ, Libby P, Goldhaber SZ. More than an anticoagulant: Do heparins have direct anti-inflammatory effects? Thromb Haemost 2017;117(3):437-444. DOI: 10.1160/TH16-08-0620.

12. Hippensteel JA, LaRiviere WB, Colbert JF, Langouet-Astrie CJ, Schmidt EP. Heparin as a therapy for COVID-19: current evidence and future possibilities. Am J Physiol Lung Cell Mol Physiol 2020;319(2):L211-L217. DOI: 10.1152/ajplung.00199.2020.

13. National Institute for Health and Care Excellence (2020). COVID-19 rapid guideline: reducing the risk of venous thromboembolism in over 16s with COVID-19 (NICE Guideline 186). Available at: https://www.nice.org.uk/guidance/ng186/ [Accessed 16 January 2021]. 
medRxiv preprint doi: https://doi.org/10.1101/2021.03.10.21252749; this version posted March 12, 2021. The copyright holder for this preprint

(which was not certified by peer review) is the author/funder, who has granted medRxiv a license to display the preprint in perpetuity.

All rights reserved. No reuse allowed without permission.

14. Nadkarni GN, Lala A, Bagiella E, et al. Anticoagulation, Bleeding, Mortality, and Pathology in Hospitalized Patients With COVID-19. J Am Coll Cardiol 2020;76(16):18151826. DOI: 10.1016/j.jacc.2020.08.041.

15. Angus DC, Berry S, Lewis RJ, et al. The REMAP-CAP (Randomized Embedded Multifactorial Adaptive Platform for Community-acquired Pneumonia) Study. Rationale and Design. Ann Am Thorac Soc 2020;17(7):879-891. DOI: 10.1513/AnnalsATS.202003192SD.

16. Houston BL, Lawler PR, Goligher EC, et al. Anti-Thrombotic Therapy to Ameliorate Complications of COVID-19 (ATTACC): Study design and methodology for an international, adaptive Bayesian randomized controlled trial. Clin Trials 2020;17(5):491500. DOI: $10.1177 / 1740774520943846$.

17. Schulman S, Kearon C, Subcommittee on Control of Anticoagulation of the S, Standardization Committee of the International Society on T, Haemostasis. Definition of major bleeding in clinical investigations of antihemostatic medicinal products in nonsurgical patients. J Thromb Haemost 2005;3(4):692-4. DOI: 10.1111/j.15387836.2005.01204.x.

18. McGlothlin AE, Viele K. Bayesian Hierarchical Models. JAMA 2018;320(22):2365-2366. DOI: 10.1001/jama.2018.17977.

19. Wijaya I, Andhika R, Huang I. The Use of Therapeutic-Dose Anticoagulation and Its Effect on Mortality in Patients With COVID-19: A Systematic Review. Clin Appl Thromb Hemost 2020;26:1076029620960797. DOI: 10.1177/1076029620960797.

20. Ionescu F, Jaiyesimi I, Petrescu I, et al. Association of anticoagulation dose and survival in hospitalized COVID-19 patients: A retrospective propensity score-weighted analysis. Eur J Haematol 2021;106(2):165-174. DOI: 10.1111/ejh.13533.

21. Tritschler T, Mathieu ME, Skeith $L$, et al. Anticoagulant interventions in hospitalized patients with COVID-19: A scoping review of randomized controlled trials and call for international collaboration. J Thromb Haemost 2020;18(11):2958-2967. DOI: 10.1111/jth.15094.

22. Libster R, Perez Marc G, Wappner D, et al. Early High-Titer Plasma Therapy to Prevent Severe Covid-19 in Older Adults. N Engl J Med 2021. DOI: 10.1056/NEJMoa2033700.

23. Horby P, Lim WS, Emberson JR, et al. Dexamethasone in Hospitalized Patients with Covid-19 - Preliminary Report. N Engl J Med 2020. DOI: 10.1056/NEJMoa2021436.

24. Salama C, Han J, Yau L, et al. Tocilizumab in Patients Hospitalized with Covid-19 Pneumonia. N Engl J Med 2021;384(1):20-30. DOI: 10.1056/NEJMoa2030340.

25. Cook D, Meade M, Guyatt $G$, et al. Dalteparin versus unfractionated heparin in critically ill patients. N Engl J Med 2011;364(14):1305-14. DOI: 10.1056/NEJMoa1014475.

26. Wichmann D, Sperhake JP, Lutgehetmann M, et al. Autopsy Findings and Venous Thromboembolism in Patients With COVID-19. Ann Intern Med 2020. DOI: 10.7326/M20-2003. 
medRxiv preprint doi: https://doi.org/10.1101/2021.03.10.21252749; this version posted March 12, 2021. The copyright holder for this preprint (which was not certified by peer review) is the author/funder, who has granted medRxiv a license to display the preprint in perpetuity.

\begin{tabular}{|c|c|c|}
\hline Characteristic & $\begin{array}{l}\text { Therapeutic } \\
\text { anticoagulation } \\
(\mathrm{N}=532)\end{array}$ & $\begin{array}{l}\text { Usual care pharmacological } \\
\text { thromboprophylaxis }(\mathrm{N}=557)\end{array}$ \\
\hline Age - mean (SD), years & $60.2(13.1)$ & $61.6(12.5)$ \\
\hline Male Sex - n/N (\%) & $383 / 532(72)$ & $379 / 557(68)$ \\
\hline \multicolumn{3}{|l|}{ Race/Ethnicity - } \\
\hline White $\mathrm{n} / \mathrm{N}(\%)$ & $314 / 423(74.2)$ & $326 / 443(73.6)$ \\
\hline Asian n/N (\%) & $69 / 423(16.3)$ & $71 / 443(16)$ \\
\hline Black n/N (\%) & $24 / 423(5.7)$ & $20 / 443(4.5)$ \\
\hline Other $n / N(\%)$ & $16 / 423(3.8)$ & $26 / 443(5.9)$ \\
\hline \multicolumn{3}{|l|}{ Country -n/N (\%) } \\
\hline United Kingdom & $388 / 532(72.9)$ & $389 / 557(69.8)$ \\
\hline United States & $78 / 532(14.7)$ & $96 / 557(17.2)$ \\
\hline Canada & $39 / 532(7.3)$ & $53 / 557(9.5)$ \\
\hline Brazil & $12 / 532(2.3)$ & $6 / 557(1.1)$ \\
\hline Other ${ }^{a}$ & $15 / 532(2.8)$ & $13 / 557(2.3)$ \\
\hline Body mass index $\left(\mathrm{kg} / \mathrm{m}^{2}\right)$ - median (IQR) & $\begin{array}{l}30.4(26.9,35.9) \\
(n=458)\end{array}$ & $\begin{array}{l}30.2(26.4,34.6) \\
(n=470)\end{array}$ \\
\hline APACHE II score ${ }^{\mathrm{b}}$ - median (IQR) & $\begin{array}{l}13(8,21) \\
(n=417)\end{array}$ & $\begin{array}{l}13(8,19) \\
(n=417)\end{array}$ \\
\hline \multicolumn{3}{|l|}{ Pre-existing conditions - n/N (\%) } \\
\hline Diabetes mellitus (type 1 or 2 ) & $168 / 523(32.1)$ & $182 / 546(33.3)$ \\
\hline Severe cardiovascular disease ${ }^{c}$ & $36 / 495(7.3)$ & $34 / 517(6.6)$ \\
\hline Chronic kidney disease & $56 / 499(11.2)$ & $40 / 502(8)$ \\
\hline Chronic respiratory disease $^{d}$ & $121 / 503(24.1)$ & $125 / 516(24.2)$ \\
\hline Chronic liver disease & $6 / 504(1.2)$ & $2 / 527(0.4)$ \\
\hline \multicolumn{3}{|l|}{ Baseline treatments ${ }^{\mathrm{e}}-\mathrm{n} / \mathrm{N}(\%)$} \\
\hline Antiplatelet agent ${ }^{f}$ & $36 / 488(7.4)$ & $42 / 516(8.1)$ \\
\hline Remdesivir & $149 / 488(30.5)$ & $161 / 517(31.1)$ \\
\hline Corticosteroids & $387 / 488(79.3)$ & $410 / 517(79.3)$ \\
\hline Tocilizumab & $9 / 488(1.8)$ & 9/517 (1.7) \\
\hline \multicolumn{3}{|l|}{ Baseline organ support $-\mathrm{n} / \mathrm{N}(\%)$} \\
\hline No oxygen/supplemental oxygen & $8 / 532(1.5)$ & $7 / 557(1.3)$ \\
\hline High flow nasal oxygen & $172 / 532(32.3)$ & $188 / 557(33.8)$ \\
\hline Non-invasive ventilation & $214 / 532(40.2)$ & $200 / 557(35.9)$ \\
\hline Invasive mechanical ventilation & $138 / 532(25.9)$ & $162 / 557(29.1)$ \\
\hline Vasopressors/inotropes & $87 / 522(16.7)$ & $100 / 548(18.2)$ \\
\hline $\mathrm{PaO}_{2} / \mathrm{FIO}_{2}{ }^{\mathrm{b}}-$ median (IQR) & $\begin{array}{l}119(89.5-159.5) \\
(n=383)\end{array}$ & $\begin{array}{l}119(92-161) \\
(\mathrm{n}=389)\end{array}$ \\
\hline \multicolumn{3}{|l|}{ Median Laboratory values (IQR) } \\
\hline D-dimer (ng/ml) & $\begin{array}{l}827(450-1740) \\
(n=185)\end{array}$ & $\begin{array}{l}890(375-1846) \\
(n=187)\end{array}$ \\
\hline $\begin{array}{l}\text { D-dimer greater than or equal } 2 \text { times site } \\
\text { upper limit of normal - } n / N(\%)\end{array}$ & $88 / 185(47.6)$ & $87 / 187(46.5)$ \\
\hline International normalized ratio & $\begin{array}{l}1.1(1-1.2) \\
(\mathrm{n}=318)\end{array}$ & $\begin{array}{l}1.1(1-1.3) \\
(n=314)\end{array}$ \\
\hline Neutrophils $\times 10^{9} / \mathrm{L}$ & $\begin{array}{l}7.9(5.5-10.6) \\
(n=438)\end{array}$ & $\begin{array}{l}7.9(5.6-10.7) \\
(n=458)\end{array}$ \\
\hline Lymphocytes $\times 10^{9} / \mathrm{L}$ & $\begin{array}{l}0.7(0.5-1) \\
(n=439)\end{array}$ & $\begin{array}{l}0.7(0.5-1) \\
(n=467)\end{array}$ \\
\hline Platelets $\times 10^{9} / \mathrm{L}$ & $247(188-317.5)$ & $245.5(185-315)$ \\
\hline
\end{tabular}


medRxiv preprint doi: https://doi.org/10.1101/2021.03.10.21252749; this version posted March 12, 2021. The copyright holder for this preprint (which was not certified by peer review) is the author/funder, who has granted medRxiv a license to display the preprint in perpetuity. All rights reserved. No reuse allowed without permission.

\section{Footnotes:}

$(n=511)$

$(n=524)$

a. Ireland, Netherlands, Australia, Nepal, Saudi Arabia, and Mexico.

b. Available in REMAP-CAP only.

c. Defined in REMAP-CAP as a baseline history of New York Heart Association class IV symptoms; defined in ACTIV-4a and ATTACC as a baseline history of heart failure, myocardial Infarction, coronary artery disease, peripheral arterial disease, or cerebrovascular disease (stroke or transient ischemic attack).

d. Defined as a baseline history of asthma, chronic obstructive pulmonary disease, bronchiectasis, interstitial lung disease, primary lung cancer, pulmonary hypertension, active tuberculosis, or through the receipt of home oxygen therapy.

e. Recent or chronic use.

f. Not included in this summary are 113 patients co-enrolled in the REMAP-CAP Antiplatelet Domain (47 assigned to therapeutic Anticoagulation, 66 to usual care pharmacological thromboprophylaxis). 
medRxiv preprint doi: https://doi.org/10.1101/2021.03.10.21252749; this version posted March 12, 2021. The copyright holder for this preprint (which was not certified by peer review) is the author/funder, who has granted medRxiv a license to display the preprint in perpetuity.

All rights reserved. No reuse allowed without permission.

\begin{tabular}{|c|c|c|}
\hline Outcome & $\begin{array}{l}\text { Therapeutic anticoagulation } \\
\qquad(n=532)\end{array}$ & $\begin{array}{l}\text { Usual care pharmacological } \\
\text { thromboprophylaxis } \\
(n=557)\end{array}$ \\
\hline \multicolumn{3}{|l|}{ Organ support-free days to day $21^{a}$} \\
\hline $\begin{array}{l}\text { No. of patients with known } \\
\text { outcome }\end{array}$ & 529 & 545 \\
\hline Median, IQR & $3(-1,16)$ & $5(-1,16)$ \\
\hline $\begin{array}{l}\text { Adjusted proportional odds ratio } \\
\qquad(95 \% \mathrm{Crl})\end{array}$ & $0.87(0.70-1.08)$ & 1 (Reference) \\
\hline Probability of futility, \% & $99.8 \%$ & - \\
\hline Probability of superiority, $\%$ & $10.6 \%$ & - \\
\hline Probability of inferiority, \% & $89.4 \%$ & - \\
\hline \multicolumn{3}{|l|}{ Survival to hospital discharge $\mathrm{a}^{\mathrm{a}}$} \\
\hline No. of patients/total no. (\%) & $340 / 529(64.3 \%)$ & $356 / 545(65.3 \%)$ \\
\hline Adjusted odds ratio $(95 \% \mathrm{Crl})$ & $0.88(0.67-1.16)$ & 1 (Reference) \\
\hline Probability of futility, \% & $98.5 \%$ & - \\
\hline Probability of superiority, $\%$ & $19.0 \%$ & - \\
\hline Probability of inferiority, $\%$ & $81.0 \%$ & - \\
\hline \multicolumn{3}{|l|}{ Major thrombotic events or death ${ }^{b}$} \\
\hline \multicolumn{3}{|l|}{ No. of patients/total no. (\%) } \\
\hline Major thrombotic events & $27 / 471(5.7 \%)$ & $49 / 476(10.3 \%)$ \\
\hline Death in hospital & $189 / 529(35.7 \%)$ & $189 / 545(34.7 \%)$ \\
\hline $\begin{array}{l}\text { Major thrombotic events or } \\
\text { death }\end{array}$ & $200 / 483(41.4 \%)$ & $211 / 494(42.7 \%)$ \\
\hline Adjusted odds ratio $(95 \% \mathrm{Crl})$ & $1.05(0.79-1.40)$ & 1 (Reference) \\
\hline Probability of futility, \% & $94.5 \%$ & - \\
\hline Probability of superiority, $\%$ & $37.0 \%$ & - \\
\hline Probability of inferiority, \% & $63.0 \%$ & - \\
\hline \multicolumn{3}{|l|}{ Major bleeding ${ }^{b}$} \\
\hline No. of patients/total no. (\%) & $15 / 482(3.1 \%)$ & $12 / 495(2.4 \%)$ \\
\hline Odds ratio $(95 \% \mathrm{Crl})^{\mathrm{a}}$ & $1.19(0.57-2.49)$ & 1 (Reference) \\
\hline Probability of futility, $\%$ & $82.9 \%$ & - \\
\hline Probability of superiority, $\%$ & $32.3 \%$ & - \\
\hline Probability of inferiority, \% & $67.7 \%$ & - \\
\hline \multicolumn{3}{|c|}{$\begin{array}{l}\text { a Composite ordinal scale consisting of survival to hospital discharge and days free of organ support to day } 21 \text {. } \\
\text { Odds ratio }>1 \text { indicates a benefit from treatment. Probabilities of benefit (proportional odds ratio }>1 \text { ), harm } \\
\text { (proportional odds ratio<1), and futility (proportional odds ratio<1.2) are computed from the posterior } \\
\text { distribution. }\end{array}$} \\
\hline
\end{tabular}


medRxiv preprint doi: https://doi.org/10.1101/2021.03.10.21252749; this version posted March 12, 2021. The copyright holder for this preprint (which was not certified by peer review) is the author/funder, who has granted medRxiv a license to display the preprint in perpetuity.

All rights reserved. No reuse allowed without permission.

Figure 1. Screening, enrollment, randomization, and inclusion in analysis. *1531 patients from the moderate state were included in the primary statistical model (see Methods for details).

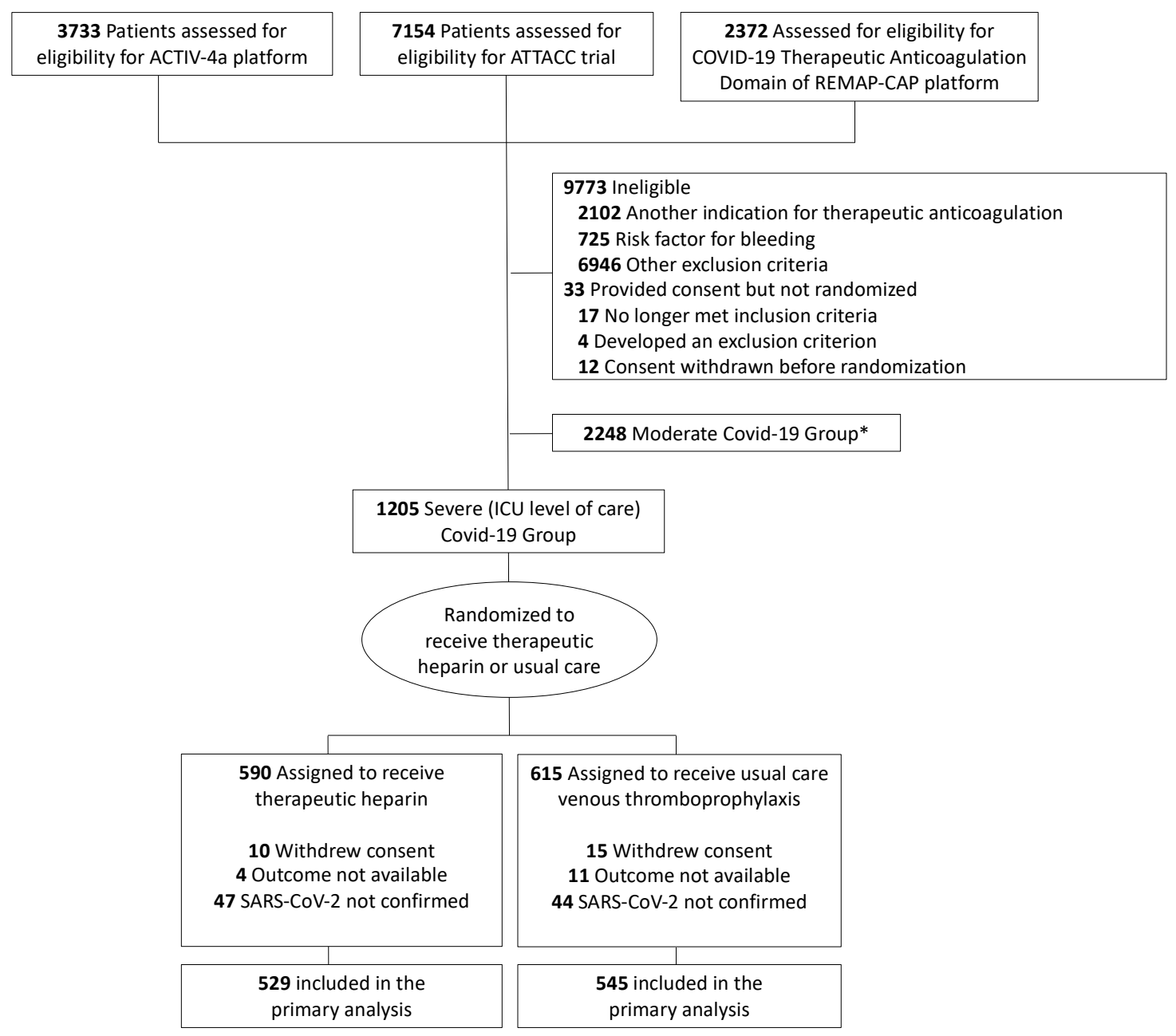


medRxiv preprint doi: https://doi.org/10.1101/2021.03.10.21252749; this version posted March 12, 2021. The copyright holder for this preprint (which was not certified by peer review) is the author/funder, who has granted medRxiv a license to display the preprint in perpetuity.

All rights reserved. No reuse allowed without permission.

Figure 2. Organ support-free days to day 21. Upper panel) the cumulative proportion (y-axis) for each intervention group by day (x-axis), with death listed first. Curves that rise more slowly indicate a more favorable distribution in the number of days alive and free of organ support. The height of each curve at "-1" indicates the in-hospital mortality rate for each intervention. The height of each curve at any point, for example, at day $=10$, indicates the proportion of patients with organ support-free days (OSFD) of 10 or lower (i.e. 10 or worse). The difference in height of the two curves at any point represents the difference in the cumulative probability of having a value for OSFDs less than or equal to that point on the x-axis. Lower panel) Organ support-free days as horizontally stacked proportions by intervention group. Red represents worse outcomes and blue represents better outcomes. The median adjusted odds ratio for the primary analysis was 0.87 (95\% credible interval $0.70-1.08$, posterior probability of futility $99.8 \%$ ).
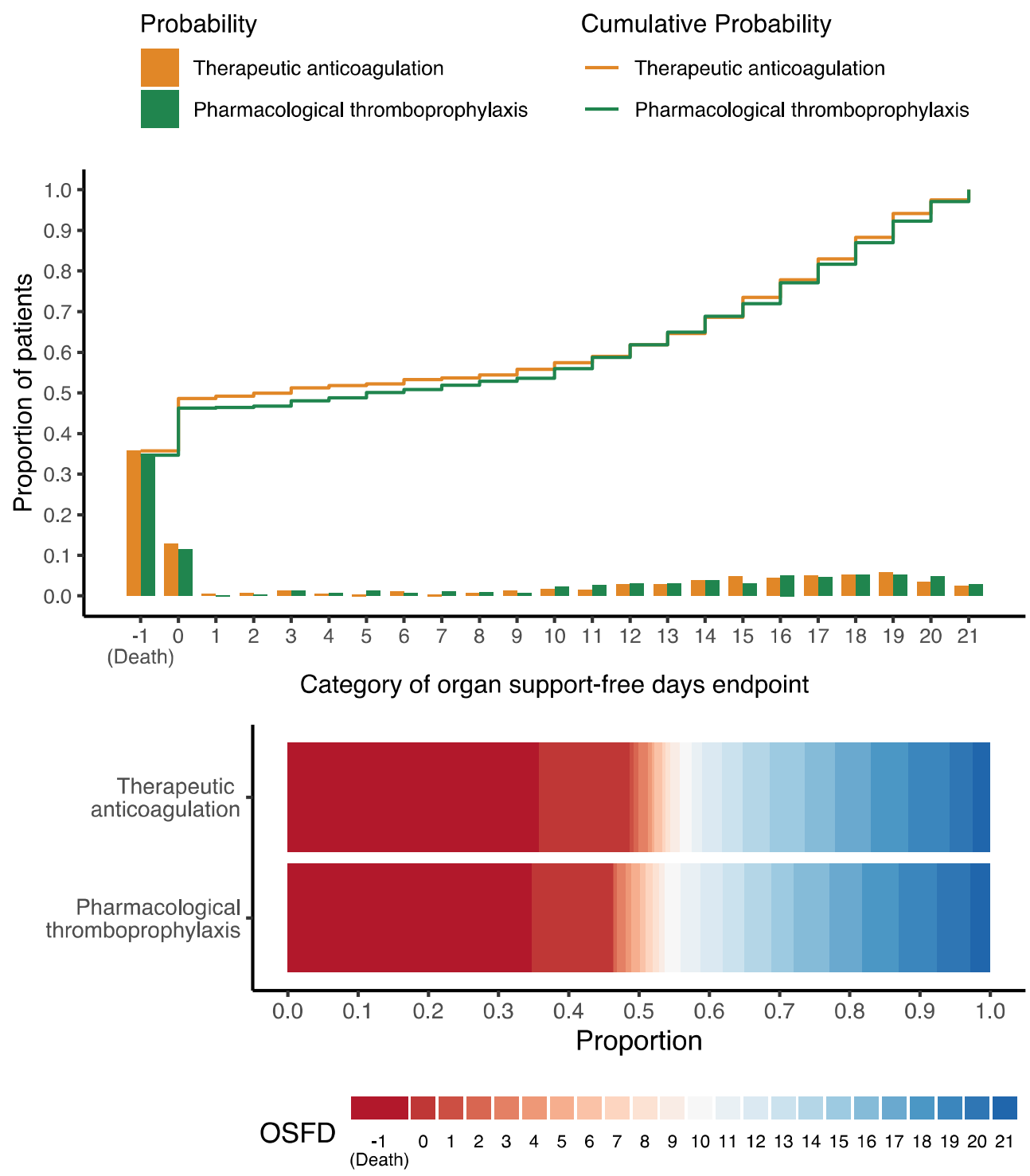
medRxiv preprint doi: https://doi.org/10.1101/2021.03.10.21252749; this version posted March 12, 2021. The copyright holder for this preprint (which was not certified by peer review) is the author/funder, who has granted medRxiv a license to display the preprint in perpetuity. All rights reserved. No reuse allowed without permission.

Figure 3. Survival to day 90 according to treatment assignment.

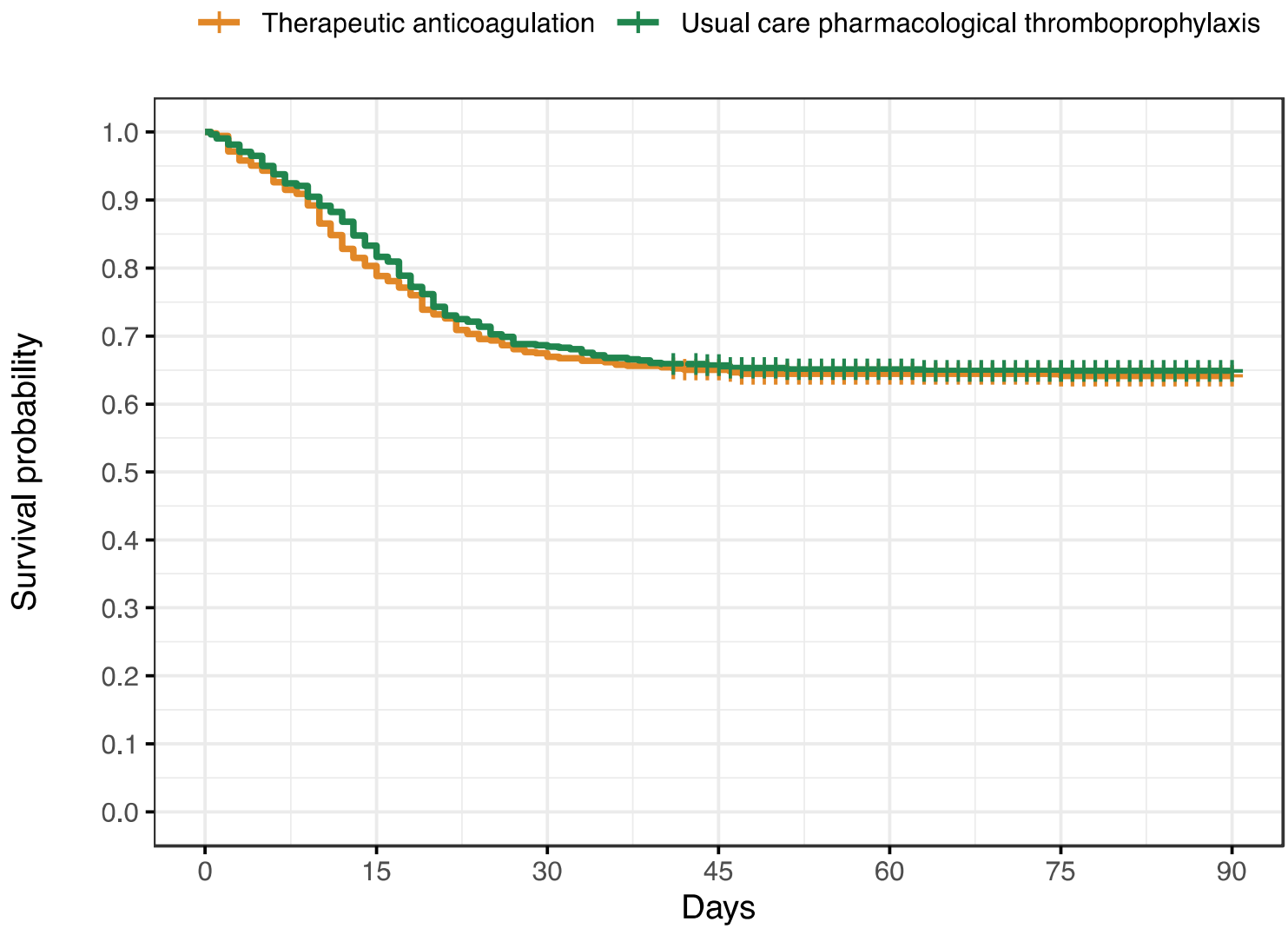

Number at risk

\begin{tabular}{|c|c|c|c|c|c|c|}
\hline 529 & 425 & 357 & 337 & 277 & 208 & 138 \\
545 & 454 & 374 & 354 & 275 & 198 & 137 \\
\hline 0 & 15 & 30 & $\begin{array}{c}45 \\
\text { Days }\end{array}$ & 60 & 75 & 90 \\
\hline
\end{tabular}




\section{Authors:}

\section{Executive Writing Committee:}

Ewan C. Goligher, M.D., Ph.D. ${ }^{* 1,2}$, Charlotte Ann Bradbury, M.B., Ch.B. ${ }^{* 3,4}$, Bryan J. McVerry, M.D.*5,6, Patrick R. Lawler, M.D. M.P.H.* 1,7, Jeffrey S. Berger, M.D. ${ }^{* 8}$, Michelle N. Gong, M.D. ${ }^{* 9,10}$, Marc Carrier, M.D., M.Sc. ${ }^{11,12}$, Harmony R. Reynolds, M.D. ${ }^{8}$, Anand Kumar, M.D. ${ }^{13,}$, Alexis F. Turgeon, M.D., M.Sc. ${ }^{14,15}$, Lucy Z. Kornblith, M.D. ${ }^{16}$, Susan R Kahn, M.D., M.Sc. ${ }^{17}$, John C. Marshall, M.D. ${ }^{18}$, Keri S. Kim, Pharm. D. ${ }^{19}$, Brett L Houston, M.D. ${ }^{13,20}$, Lennie P. G. Derde, M.D., Ph.D. ${ }^{21}$, Mary Cushman, M.D., M.Sc. ${ }^{22}$, Tobias Tritschler, M.D., M.Sc. ${ }^{23}$, Derek C. Angus, M.D., M.P.H. ${ }^{5,6}$, Lucas C. Godoy, M.D. ${ }^{1,7,24}$, Zoe McQuilten, Ph.D. ${ }^{25}$, Bridget-Anne Kirwan, Ph.D. ${ }^{26,27}$, Michael E. Farkouh, M.D. ${ }^{1,7}$, Maria M. Brooks, Ph.D. ${ }^{5}$, Roger J. Lewis, M.D., Ph.D. ${ }^{28,29}$, Anthony C. Gordon, M.B.B.S., M.D. ${ }^{30,31}$, Scott M. Berry, Ph.D. ${ }^{* * 28}$, Colin J. McArthur, M.B., Ch.B. ${ }^{* * 25,32,33}$, Matthew D. Neal, M.D. ${ }^{* * 5,6}$, Judith S. Hochman, M.D. ${ }^{* * 8}$, Steven A. Webb, M.P.H., Ph.D. $* * 25,34$, Ryan Zarychanski, M.D., M.Sc. $* * 13,20$

\section{$*, * *$ denotes equal contribution}

\section{Block Writing Committee: (In alphabetical order)}

Tania Ahuja, Pharm.D. ${ }^{35}$, Farah Al-Beidh, Ph.D. ${ }^{30}$, Djillali Annane, M.D., Ph.D. ${ }^{36}$, Yaseen M. Arabi, M.D. ${ }^{37,38}$, Diptesh Aryal, M.D. ${ }^{39,40}$, Lisa Baumann Kreuziger, M.D. ${ }^{41}$, Abi Beane, Ph.D. ${ }^{42,43}$, Lindsay R. Berry, Ph.D. ${ }^{28}$, Zahra Bhimani, M.P.H. ${ }^{18}$, Shailesh Bihari, Ph.D. ${ }^{44}$, Henny H. Billett, M.D., M.Sc. ${ }^{9,10}$, Lindsay Bond ${ }^{45}$, Marc Bonten, Ph.D. ${ }^{21}$, Frank Brunkhorst ${ }^{46}$, Meredith Buxton, Ph.D. ${ }^{47}$, Adrian Buzgau ${ }^{25}$, Lana A. Castellucci, M.D., M.Sc. ${ }^{11,48}$, Sweta Chekuri, M.D. ${ }^{9}$, Jen-Ting Chen, M.D., M.S. ${ }^{9}$, Allen C. Cheng, Ph.D. ${ }^{49,50}$, Tamta Chkhikvadze, M.D. ${ }^{8,35}$, Benjamin Coiffard, M.D., M.Sc. ${ }^{51}$, Aira Contreras, M.A. ${ }^{8,35}$, Todd W. Costantini, M.D. ${ }^{52}$, Sophie de Brouwer, Ph.D. ${ }^{26}$, Michelle A. Detry, Ph.D. ${ }^{28}$, Abhijit Duggal, M.D., M.P.H., M.Sc. ${ }^{53}$, Vladimír Džavík, M.D. ${ }^{1,7}$, Mark B. Effron, M.D. ${ }^{54}$, Heather F. Eng, BA ${ }^{5}$, Jorge Escobedo, M.D. ${ }^{55}$, Lise J. Estcourt, M.B.B.Chir., D.Phil. ${ }^{33,}{ }^{42}$, Brendan M. Everett, M.D., M.P.H. ${ }^{56}$, Dean A. Fergusson, Ph.D. ${ }^{11,48}$, Mark Fitzgerald, Ph.D. ${ }^{28}$, Robert A. Fowler, M.D. ${ }^{1}$, Joshua D. Froess, M.S. ${ }^{5}$, Zhuxuan Fu, M.S., M.P.H. ${ }^{5}$, Jean Philippe Galanaud, M.D. ${ }^{1,57}$, Benjamin T. Galen, M.D. ${ }^{10}$, Sheetal Gandotra, M.D. ${ }^{58}$, Timothy D. Girard, M.D. ${ }^{59}$, Andrew L. Goodman, M.D. ${ }^{60}$, Herman Goossens, M.D. ${ }^{61}$, Cameron Green, M.Sc. ${ }^{25}$, Yonatan Y. Greenstein, M.D. ${ }^{62}$, Peter L. Gross, M.D. ${ }^{63,64}$, M.Sc., Rashan Haniffa, Ph.D. ${ }^{65,66}$, Sheila M. Hegde, M.D., M.P.H. ${ }^{67}$, Carolyn M. Hendrickson, M.D. ${ }^{16}$, Alisa M. Higgins, Ph.D. ${ }^{25}$, Alexander A. Hindenburg, M.D. ${ }^{68}$, Aluko A. Hope, M.D., M.S.C.E. ${ }^{9,10}$, James M. Horowitz, M.D. ${ }^{35}$, Christopher M. Horvat, M.D., M.H.A. ${ }^{69}$, David T. Huang, M.D. ${ }^{5}$, Kristin Hudock, M.D., M.S.T.R. ${ }^{70}$, Beverley J. Hunt, O.B.E. ${ }^{71}$, Mansoor Husain, M.D. ${ }^{1,2}$, Robert C. Hyzy, M.D. ${ }^{72}$, Jeffrey R. Jacobson, M.D. ${ }^{19}$, Devachandran Jayakumar, M.D. ${ }^{73}$, Norma M. Keller, M.D. ${ }^{8,74}$, Akram Khan, M.D. ${ }^{75}$, Yuri Kim, M.D., Ph.D. ${ }^{56}$, Andrei Kindzelski, M.D., Ph.D. ${ }^{76}$,Andrew J. King, Ph.D. ${ }^{5}$, M. Margaret Knudson, M.D. ${ }^{16}$, Aaron E. Kornblith, M.D. ${ }^{16}$, Matthew E. Kutcher, M.D., M.S. ${ }^{77}$, Michael A. Laffan, D.M. ${ }^{30}$, Francois Lamontagne, M.D. ${ }^{78}$, Grégoire Le Gal, M.D., Ph.D. ${ }^{11,12}$, Christine M. Leeper, M.D., M.Sc. ${ }^{5}$, Eric Leifer, Ph.D. ${ }^{76}$, George Lim, M.D. ${ }^{79}$, Felipe Gallego Lima, M.D. ${ }^{24}$, Kelsey Linstrum, M.S. ${ }^{5,6}$, Edward Litton, Ph.D. ${ }^{34,80}$, Jose Lopez-Sendon, Ph.D. ${ }^{81}$, Elizabeth Lorenzi, Ph.D. ${ }^{28}$, Sylvain A. Lother, M.D. ${ }^{13}$, Nicole Marten, R.N. ${ }^{82}$, Andréa Saud Marinez, Pharm.D., M.Sc. ${ }^{83}$, Mary Martinez, M.S. ${ }^{5}$, Eduardo Mateos Garcia, M.D., M.Sc. ${ }^{55}$, Stavroula Mavromichalis, M.A. ${ }^{8,33}$, Daniel F. McAuley, M.D. ${ }^{84,85}$, Emily G. McDonald, M.D., M.Sc. ${ }^{17}$, Anna 
medRxiv preprint doi: https://doi.org/10.1101/2021.03.10.21252749; this version posted March 12, 2021. The copyright holder for this preprint (which was not certified by peer review) is the author/funder, who has granted medRxiv a license to display the preprint in perpetuity. All rights reserved. No reuse allowed without permission.

McGlothlin, Ph.D. ${ }^{28}$, Shay P. McGuinness, M.B., Ch.B. ${ }^{25,86}$, Saskia Middeldorp, M.D., Ph.D. ${ }^{87}$, Stephanie K. Montgomery, M.Sc. ${ }^{5}$, Paul R. Mouncey, M.Sc. ${ }^{88}$, Srinivas Murthy, M.D. ${ }^{89}$, Girish B. Nair, M.D., M.S. ${ }^{90,91}$, Rahul Nair, M.D. ${ }^{9}$, Alistair D. Nichol, M.B., Ph.D. ${ }^{25,50,92}$, Jose C. Nicolau, M.D., Ph.D. ${ }^{24}$, Brenda Nunez-Garcia, BA ${ }^{16}$, John J. Park, B.S. ${ }^{16}$, Pauline K. Park, M.D. ${ }^{72}$, Rachael L. Parke, Ph.D. ${ }^{86,93}$, Jane C. Parker, B.N. ${ }^{25}$, Sam Parnia, M.D., Ph.D. ${ }^{8}$, Jonathan D. Paul, M.D. ${ }^{94}$, Mauricio Pompilio, Ph.D. ${ }^{95,96}$, John G. Quigley, M.D. ${ }^{19}$, Robert S. Rosenson, M.D. ${ }^{97,98}$, Natalia S. Rost, M.D. ${ }^{99,100}$, Kathryn Rowan, Ph.D. ${ }^{88}$, Fernanda O. Santos ${ }^{101}$, Marlene Santos, M.D., M.Sc. ${ }^{18}$, Mayler Olombrada Santos, M.Sc. ${ }^{102}$, Lewis Satterwhite, M.D. ${ }^{103}$, Christina T. Saunders, Ph.D. ${ }^{28}$, Jake Schreiber, M.B.A., M.P.H. ${ }^{104}$, Roger E.G. Schutgens, M.D., Ph.D. ${ }^{21,105}$, Christopher W. Seymour, M.D. ${ }^{5}$, Deborah M. Siegal, M.D., M.Sc. ${ }^{11,48}$, Delcio Goncalves Silva Jr., M.Med. ${ }^{106,107}$, Aneesh B. Singhal, M.D. ${ }^{99,100}$, Arthur S. Slutsky, M.D. ${ }^{1,18}$, Dayna Solvason ${ }^{13}$, Simon J. Stanworth, F.R.C.P., D.Phil. ${ }^{33,42}$, Anne M. Turner, M.P.H. ${ }^{108}$, Wilma van Bentum-Puijk, M.Sc. ${ }^{21}$, Frank L. van de Veerdonk, M.D., Ph.D. ${ }^{87}$, Sean van Diepen, M.D., M.Sc. ${ }^{109}$, Gloria Vazquez-Grande, M.D., M.Sc. ${ }^{13}$, Lana Wahid, M.D. ${ }^{110}$, Vanessa Wareham, H.B.Sc. ${ }^{45}$, R. Jay Widmer, M.D., Ph.D. ${ }^{111}$, Jennifer G. Wilson, M.D. ${ }^{112}$, Eugene Yuriditsky, M.D. ${ }^{35}$, Yongqi Zhong, M.B., M.P.H. ${ }^{5}$. 
1 University of Toronto, Toronto, Canada

2 University Health Network, Toronto, Canada

3 University of Bristol, Bristol, United Kingdom

4 University Hospitals Bristol and Weston NHS Foundation Trust, Bristol, United Kingdom

5 University of Pittsburgh, Pittsburgh, United States

6 UPMC, Pittsburgh, United States

7 Peter Munk Cardiac Centre at University Health Network, Toronto, Canada

8 NYU Grossman School of Medicine, New York City, United States

9 Montefiore Medical Center, Bronx, United States

10 Albert Einstein College of Medicine, Bronx, United States

11 Ottawa Hospital Research Institute, Ottawa, Canada

12 Institut du Savoir Montfort, Ottawa, Canada

13 University of Manitoba, Winnipeg, Canada

14 Université Laval, Québec City, Canada

15 CHU de Québec - Université Laval Research Center, Québec City, Canada

16 Zuckerberg San Francisco General Hospital/University of California, San Francisco, United States

17 McGill University, Montreal, Canada

18 St. Michael's Hospital Unity Health, Toronto, Canada

19 University of Illinois, Chicago, United States

20 CancerCare Manitoba, Winnipeg, Canada

21 University Medical Center Utrecht, Utrecht University, Utrecht, The Netherlands

22 Larner College of Medicine at the University of Vermont, Burlington, United States

23 Inselspital, Bern University Hospital, University of Bern, Switzerland

24 Instituto do Coração (InCor), Hospital das Clínicas HCFMUSP, Universidade de São Paulo, São Paulo, Brazil

25 Australian and New Zealand Intensive Care Research Centre, Monash University, Melbourne, Australia

26 SOCAR Research SA, Nyon, Switzerland

27 London School of Hygiene and Tropical Medicine, London, UK

28 Berry Consultants, LLC, Austin, United States

29 Harbor-UCLA Medical Center, Torrance, United States

30 Imperial College London, London, United Kingdom

31 Imperial College Healthcare NHS Trust, St. Mary's Hospital, London, United Kingdom

32 Auckland City Hospital, Auckland, New Zealand

33 NHS Blood and Transplant, Oxford, United Kingdom

34 St John of God Hospital, Subiaco, Australia

35 NYU Langone Health, NYU Langone Hospital, New York City, United States

36 Fédération Hospitalo Universitaire SEPSIS, Garches, France

37 King Saud bin Abdulaziz University for Health Sciences, Riyadh, Kingdom of Saudi Arabia

38 King Abdullah International Medical Research Center, Riyadh, Kingdom of Saudi Arabia

39 Nepal Mediciti Hospital, Lalitpur, Nepal 
40 Nepal Intensive Care Research Foundation, Kathmandu, Nepal

41 Versiti Blood Research Institute, Milwaukee, United States

42 Oxford University, Oxford, United Kingdom

43 NICS-MORU, Colombo, Sri Lanka

44 Flinders University, Bedford Park, Australia

45 Ozmosis Research Inc., Toronto, Ontario

46 Jena University Hospital, Jena, Germany

47 Global Coalition for Adaptive Research, Los Angeles, United States

48 University of Ottawa, Ottawa, Canada

49 Monash University, Melbourne, Australia

50 Alfred Health, Melbourne, Australia

51 Aix-Marseille University, Marseille, France

52 University of California San Diego School of Medicine, San Diego, United States

53 Cleveland Clinic, Cleveland, Ohio

54 Ochsner Medical Center, University of Queensland-Ochsner Clinical School, New Orleans, United States

55 Instituto Mexicano del Seguro Social, Mexico City, Mexico

56 Harvard Medical School and Brigham and Women's Hospital, Boston, United States

57 Sunnybrook Health Sciences Centre, Toronto, Canada

58 University of Alabama, Birmingham, United States

59 The Clinical Research, Investigation, and Systems Modeling of Acute Illness (CRISMA) Center, University of Pittsburgh, Pittsburgh, United States

60 TriStar Centennial Medical Center, Nashville, United States

61 University of Antwerp, Wilrijk, Belgium

62 Rutgers New Jersey Medical School, Newark, United States

63 McMaster University, Hamilton, Canada

64 Thrombosis and Atherosclerosis Research Institute, Hamilton, Canada

65 University of Oxford, Bangkok, Thailand

66 University College London Hospital, London, United Kingdom

67 Brigham and Women's Hospital, Boston, United States

68 NYU Langone Long Island, Mineola, United States

69 UPMC Children's Hospital of Pittsburgh, Pittsburgh, United States

70 University of Cincinnati, Cincinnati, United States

71 Kings Healthcare Partners, London, United Kingdom

72 University of Michigan, Ann Arbor, United States

73 Apollo Speciality Hospital - OMR, Chennai, India

74 Bellevue Hospital, New York City, United States

75 Oregon Health \& Science University, Portland, United States

76 National Heart Lung and Blood Institute, National Institutes of Health, Bethesda, MD, United States

77 University of Mississippi Medical Center, Jackson, United States

78 Université de Sherbrooke, Sherbrooke, Canada

79 University of California Los Angeles, Los Angeles, United States

80 Fiona Stanley Hospital, Perth, Australia 
81 IdiPaz Research Institute, Universidad Autonoma, Madrid, Spain

82 St Boniface Hospital, Winnipeg, Canada

83 Avanti Pesquisa Clínica, Sao Paulo, Brazil

84 Queen's University Belfast, Belfast, Northern Ireland

85 Royal Victoria Hospital, Belfast, Northern Ireland

86 Auckland City Hospital, Auckland, New Zealand

87 Radboud University Medical Center, Nijmegen, The Netherlands

88 Intensive Care National Audit \& Research Centre (ICNARC), London, United Kingdom

89 University of British Columbia, Vancouver, Canada

90 Beaumont Health, Royal Oak, United States

91 OUWB School of Medicine, Auburn Hills, United States

92 University College Dublin, Dublin, Ireland

93 The University of Auckland, Auckland, New Zealand

94 University of Chicago, Chicago, United States

95 Hospital do Coração de Mato Grosso do Sul (HCMS), Campo Grande, Brazil

96 Federal University of Mato Grosso do Sul (UFMS), FAMED, Campo Grande, Brazil

97 Icahn School of Medicine at Mount Sinai, New York City, United States

98 Mount Sinai Heart, New York City, United States

99 Massachusetts General Hospital, Boston, United States

100 Harvard Medical School, Boston, United States

101 Hospital 9 de Julho, São Paulo, Brazil

102 INGOH, Clinical Research Center, Goiânia, Brazil.

103 University of Kansas School of Medicine, Kansas City, United States

104 The Chartis Group, Chicago, United States

105 University Utrecht, Utrecht, The Netherlands

106 Hospital Universitário Maria Aparecida Pedrossia, Campo Grande, Brazil

107 Hospital Unimed Campo Grande, Campo Grande, Brazil

108 Medical Research Institute of New Zealand, Wellington, New Zealand

109 University of Alberta, Edmonton, Canada

110 Duke University Hospital, Durham, North Carolina

111 Baylor Scott and White Health, Temple, United States

112 Stanford University School of Medicine, Palo Alto, United States 